\title{
Entrepreneurial activity and family business in the period of reformation of the Russian legislation
}

\author{
Olga Yuryevna Ilyina $^{1 *}$, Marina Sergeevna Ruzhentseva², Svetlana Andreevna Safronova ${ }^{2}$, \\ Aleksandr Vasilyevich Tyulin ${ }^{3}$, and Aryuvseit Arabidinovna Artemyeva ${ }^{3}$ \\ ${ }^{1}$ Tver State University, Department of Civil Law, Tver, Russia \\ ${ }^{2}$ Moscow Finance and law University (MFUA), Department Civil law disciplines, Moscow, Russia \\ ${ }^{3}$ Moscow University for Industry and Finance "Synergy", Department of Legal Disciplines, Moscow, \\ Russia
}

\begin{abstract}
Many sciences meet in the study of family business as a real phenomenon. Despite the fact that in most countries of the world, family business is a rather widespread and highly demanded legal phenomenon, in Russia family business is realized not so often and for the most part, remains strange for an ordinary entrepreneur. Family business in Russia seems to be a phenomenon that is not studied completely but requires special attention. Objective of the research: determination of the essence and main tendencies of the development of legal regulation of the entrepreneurial activity and family business in the period of reformation of the Russian legislation. This scientific research applied a dialectical method of cognition of legal processes and phenomena, used the general scientific methods of scientific cognition of the legal essence of entrepreneurial activity and family business, in particular, a historical method, a method of synthesis, analogy, formal logics, and also specific scientific methods of research of family business and business processes in the post-reform period. Results and novelty: Family business shall be a systemic element that connects the state with small and medium businesses. The introduction of such a form of business activity (family business) shall eliminate the problems and defects of legal regulation of issues arising when business is carried out by family members. It seems necessary to consider the entrepreneurial activity and family business as individual economic and legal phenomena and a grounding of family business as an independent complex legal institution. It is offered to specify the family (spouse) business as a legal entity in the law. Such changes are directed to the efficient legal regulation and establishment of economic conditions for strengthening of family business and development of the family as a social and economic community. The features of the special legal regime of the entrepreneurial activity of spouses are revealed.
\end{abstract}

*Corresponding author: kinder_advokat@rambler.ru 
Keywords: entrepreneurial activity, family business, legal regulation, reforming, Russian legislation

\section{Introduction}

Due to the serious social and economic and political changes that took place in Russia in the 1990 s, the state-run economy and the heavy state regulation were replaced by the market economy with its system of economic stimuli and special restrictions and prohibitions set by the federal law [1]. It seems that today, one can say with great confidence that actually, family business exists in the Russian Federation; however, from the point of view of the current legislation, such a form of entrepreneurial activity is not provided in Russia.

For the economy of many countries, family business is an important social and legal phenomenon. However, in the Russian Federation, there is no legal basis for the development of family business. At the same time, in the national doctrine, the concept of family business has been actively discussed and approved already for many years. National science nowadays is searching for optimal ways of solution of the social and economic problems of the society, provision of rights of citizens guaranteed by the Constitution of the Russian Federation and federal legislation. One should agree with the opinion expressed in the doctrine that the achievement of these objectives is promoted to a great extent by the entrepreneurial activity performed by spouses and other family members [2].

It should be mentioned that business can be created individually or by a group of people who are friends, know each other well; in this case, the enterprise is established by partners on the basis of a partnership. However, often a new enterprise is organized by relatives, close or distant members of the same family. In the world terminology, such companies got the name "family firm" or "family business". At the same time, to remain a family business, it should be to a certain degree limited and dependent on the "family" that established it [3].

The authors believe that in the context of the world financial crisis aggravated by the consequences of COVID-19, small forms of business are the most vulnerable. Obviously, the interests of the small business entities that include family business require special protection also within the frameworks of civil law.

\section{Results}

At the same time, the entrepreneurial activity of spouses pursues the aim of solving two problems: the solution of financial and economic problems inside the family, and also the solution of economic problems of the state within the frameworks of its internal economic policy. In the theory of entrepreneurship law, the sphere of family business and entrepreneurship based upon the family form of business process organization is of special interest. The current legislation does not define the term "economic activity" and from the point of view of practice and doctrine, it is impossible to separate clearly the notions of entrepreneurial activity and economic activity [4].

One should specially mention that in everyday life, one faces family businesses rather often. Some of the world-famous brands started from family businesses, for example: L'Oreal, Michelin, Ford Motors Co., Wal-Mart Stores, Ito-Yokado, etc. [5]. The authors agree with the scientists, and in particular with Kulakov who has reasons to believe that family business has an invaluable meaning for the economy of any legal order [6].

"Modern conditions are characterized by the change of social needs in the new forms of organization of family life and conditions of regulations of family relations" [7]. The phenomenon of family business is studied by many sciences and branches of law. Family business or family entrepreneurship can be considered from one or another point of view as 
an economic, social, cultural, and law category, also family business can be studied by the theory of household.

The authors believe family entrepreneurship is business administration by the members of one family, based upon family and marital relations or joint property of the spouses for business assets, shares, or other property of the spouses. In general, based upon the initiative proposed by the law-enforcer and law-maker, it is necessary to support the legislative initiative to legalize the notion "family business" that like "social business" can become an efficient anti-crisis legal means of solving the social and economic, legal and demographic problems of the Russian population, society, and state.

\section{Discussion}

In recent years, the issue of urgent introduction of a special federal law directed to the regulation of family business has been actively discussed at the doctrinal level and in practice. It is expected that the placement of the document "On amendments into the Federal law "On the development of small and medium business in the Russian Federation" regarding the approval of the notion of "family business" (hereinafter - Draft legislation of family business) on the federal portal of statutes and regulations drafts that were prepared at the beginning of 2020 by the Ministry of Economic Development of the Russian Federation shall be considered as a proposal for discussion about the advantages and disadvantages of this law-making approach.

The essence of the law-making idea is to reveal the special target group among the entities of small and medium business that requires additional state support - "family businesses". For this, it is proposed to make amendments in the Federal Law No. 209-FZ: in Art. 3 definitions of "family business" and "family members", and in Art. 24.2 - criteria of family businesses as the conditions of their state support. The similar approach that was optimistically shared by the expert society [8] has already been tested earlier when legalizing the notions of "social entrepreneurship" and "social business" in June 2019 in the Federal Law No. 245-FZ (hereinafter - Law of social entrepreneurship)

The generally accepted and primary advantage of this law-making approach [9] is that it is proposed to execute the Decree of the President of the Russian Federation No. 204 dd. May 07, 2018 "On national goals and strategic objectives of the development of the Russian Federation for the period up to 2024" in the framework of the implementation of the national project "Small and medium business and support of individual business initiative" financed by the federal budget. In the context of efforts undertaken by the Government of the Russian Federation to reduce by half the critical level of poverty, any secured law-making initiatives directed to the improvement of life quality of the Russian citizens shall be welcomed.

In the legal literature, the necessity of distinguishing and considering the whole "potential of family business" has been emphasized many times [10]. Being completely agreed with the said opinion, the authors shall mention that the search for such highlight, potential shall be started from the study of family legislation through the prism of entrepreneurship, corporate, and civil legislation. "Development of the modern legal relations promotes the increase in the number of contractual relationships together with which the compensated rendering of services is developed and the interbranch regulations are getting more difficult" [11].

It is commonly known that family business has deep historical roots and developed stage by stage due to the transit from one epoch to the other. Due to this, it can be confirmed that the number of its functions is changing gradually. The function of self-sufficiency can be considered as one of the primary functions of family business. The growth of the family as the owner of the family business allows it to be not only the party to family and marital relations but also an economic entity in the certain market of works or services [12]. 
The scientific discussions about the impact of the family on the entity of business have existed for many years. Nevertheless, many problems and issues of organizational, legal, and methodological nature are left unsolved. As Ershova fairly mentions, Russian legal science still has to develop the doctrine of family business [13].

In the theory of business law, the sphere of family business and entrepreneurship draws special attention, it is based upon the family form of organization of business processes. There is no legal definition of family business in Russian legislation. The doctrine of business law offers various definitions of family business. Thus, Nazarova proposes to use this term to define "any business, the significant part of ownership or management of which belongs to the members of one family working in this business" [14]. It should be mentioned that the notion "business" is used in the Civil Code of the Russian Federation as a subject of rights, property complex and therefore the proposed definition does not allow determining sufficiently the sphere of family business as family members may not have labor relations with a legal entity but however they can manage the business.

When reforming the legislation that regulates business and commercial relationships, there appeared new rules of some new special contractual structures established between the family members [15].

The content of legislation regarding the regulation of the business of family members is made up of the legal norms having a complex, public and private character. The objectives of legal regulation of business relations, the goals of their achievements, as well as such principles as managing landmarks of family business regulation, become the prerequisites of making public the entrepreneurship as well as the family legislation [16].

\section{Conclusion}

Nowadays, the participation of a family and its members in the ownership and management of business is a quite important and practice-oriented process, as it reflects its character completely only when this can influence the goals, selected strategies, and organizational structures of business entities.

It is reasoned that for the population of Russia that has always based itself upon the traditional family values, family business is a rather attractive phenomenon. Such a model of business organization is reasonable and efficient as financial investments are too much for one person, it is rather difficult to organize the business processes alone, and to attract the third parties to the management of the common business is not always rational and certainly it is risky.

The authors believe that such a model of the organization of business processes as family business is an efficient form of business entity that solves some social and economic problems as it promotes the strengthening of the family standards, keeps the family as a social institution, allows decreasing the unemployment, creating working places, forms the middle class, provides the ability to combine the business activity with household and growing of children.

The most optimal proposal that meets all the requirements is the proposal of the introduction of such forms of business as family business into the national legislation by means of approval of the federal law. It seems that the model of the legal regulation of the family business through the united specialized law is the best solution in comparison with the model of making tens of amendments into various legislative acts of Russia. 


\section{References}

1. A.A. Mokhov, A.N. Levushkin, A.N. Yavorsky, J. Adv. Res. Law Econ. 11(2-48), 483-490 (2020). https://doi.org/10.14505/jarle.v11.2(48).21

2. A.A. Mokhov, Medical Law, 1, 6-10 (2016)

3. A.N. Levushkin, Actual Problems of Russian Law, 11(96), 19-25 (2018). https://doi.org/10.17803/1994-1471.2018.96.11.019-025

4. I.V. Bakaeva, Laws of Russia: Experience, Analysis, Practice, 3, 15-21 (2018)

5. K.S. Shipitsyna, Fundamental Research, 8-3, 633-635 (2015)

6. V.V. Kulakov, Nekotorye aspekty konkretizatsii norm obyazatelstvennogo prava primenitelno $k$ institutu semeinogo biznesa [Some aspects of norm concretization of law of obligations in respect to the institution of family business], in I.V. Ershova, A.N. Levushkin (eds.), Semeinyi biznes v pravovom prostranstve Rossii [Family business in the legal framework of Russia], 165-174 (Prospekt, Moscow, 2020). https://doi.org/10.31085/9785392299539-2020-624

7. O.Yu. Ilyina, Family and Housing Law, 1, 14-17 (2019)

8. A.A. Moskovskaya, World of Social Entrepreneurship, 10, 4-11 (2019)

9. A.V. Barkov, Ya.S. Grishina, Bulletin of the Saratov State Law Academy, 5, 92-99 (2019)

10. L.A. Barkova, Semeinoe predprinimatelstvo v mekhanizme pravovogo obespecheniya garmonizatsii interesov semi [Family business in the mechanism of legal support of harmonization of family interests], $\mathrm{PhD}$ thesis (Moscow Academy of Economy and Law, Moscow, 2015)

11. A.N. Levushkin, I.V. Zaikina, M.A. Bulavina, G.A. Kozlitin, V.V. Zaikin, PalArch's J. Archaeol. Egypt/Egyptol. 17(6), 6964-6973 (2020)

12. A.N. Levushkin, Laws of Russia: Experience, Analysis, Practice, 4, 25-29 (2018)

13. I.V. Ershova, Semeinyi biznes - yavlenie unikalnoe i ne do kontsa izuchennoe [Family business is a unique, not completely studied phenomenon], in I.V. Ershova, A.N.

Levushkin (eds.), Semeinyi biznes v pravovom prostranstve Rossii [Family business in the legal framework of Russia], 44-55 (Prospekt, Moscow, 2020).

https://doi.org/10.31085/9785392299539-2020-624

14. T.Yu. Nazarova, Semeinoe predprinimatelstvo v Rossiiskoi Federatsii: napravleniya razvitiya [Family business in the Russian Federation: trends of development], $\mathrm{PhD}$ thesis (Derzhavin Tambov State University, Tambov, 2008)

15. V.G. Golyshev, A.V. Golysheva, O.V. Efimova, E.V. Pitko, A.N. Levushkin, Revista Inclusiones, 7, 229-239 (2020)

16. Y.G. Leskova, A.N. Levushkin, S.Yu. Morozov, V.V. Romanov, S.G. Poberezhny, L.E. Rakhmatullina, Int. J. Econ. Bus. Adm. 8(4), 700-709 (2020) 